\title{
CCR5 genotype and plasma ß-chemokine concentration of Brazilian HIV-infected individuals
}

A.Y. Mikawa ${ }^{1}$, S.A. Tagliavini ${ }^{1}$ and P.I. Costa ${ }^{2}$
1Pós-Graduação em Biotecnologia, Instituto de Química, Universidade Estadual Paulista, Araraquara, SP, Brasil

${ }^{2}$ Laboratório de Imunologia Clínica, Departamento de Análises Clínicas, Faculdade de Ciências Farmacêuticas, Universidade Estadual Paulista, Araraquara, SP, Brasil

\section{Correspondence}

A.Y. Mikawa

Laboratório de Imunologia Clínica

Departamento de Análises Clínicas FCF, UNESP

Rua Expedicionários do Brasil, 1621

14801-902 Araraquara, SP

Brasil

Fax: +55-16-3301-6100

E-mail: costapi@fcfar.unesp.br

Presented at the XVI Annual Meeting of the Federação de Sociedades de Biologia Experimental, Caxambu, MG, Brazil, August 29 - September 1, 2001.

Presented at the 3rd Congress of Pharmaceutical Sciences, Águas de Lindóia, SP, Brazil, April 8-11, 2001.

Research supported by CAPES and Núcleo de Atendimento à Comunidade (NAC) of the Pharmaceutical Sciences Faculty, UNESP, Araraquara, SP, Brazil. Publication supported by FAPESP.

Received September 24, 2001 Accepted August 22, 2002

\section{Abstract}

The 32-bp deletion in the HIV-1 co-receptor CCR5 confers a high degree of resistance to HIV-1 infection in homozygous individuals for the deleted allele and partial protection against HIV-1 during disease progression in heterozygotes. Natural ligands for CCR5, MIP-1 $\alpha$, MIP-1ß and RANTES, have been shown to inhibit HIV replication in CD4+ T cells. In the present study, we examined the CCR5 genotype by PCR and the plasma levels of RANTES and MIP-1 $\alpha$ by ELISA among blood donors $(\mathrm{N}=26)$ and among HIV-1-infected individuals $(\mathrm{N}=129)$. The control group consisted of healthy adult volunteers and HIV-1-infected subjects were an asymptomatic and heterogeneous group of individuals with regard to immunologic and virologic markers of HIV-1 disease. The frequency of the CCR5 mutant allele $(\Delta 32 \mathrm{ccr} 5)$ in this population was 0.032 ; however, no $\Delta 32 \mathrm{ccr} 5$ homozygote was detected. These results could be related to the intense ethnic admixture of the Brazilian population. There was no correlation between circulating $\beta$-chemokines (MIP- $1 \alpha$, RANTES) and viral load in HIV-infected individuals. RANTES concentrations in plasma samples from HIV+ patients carrying the homozygous CCR5 allele (CCR5/CCR5) $(28.23 \mathrm{ng} / \mathrm{ml})$ were higher than in the control samples $(16.07 \mathrm{ng} / \mathrm{ml} ; \mathrm{P}<0.05)$; however, this $\mathrm{HIV}+$ patient group (mean 26.23 $\mathrm{pg} / \mathrm{ml}$ ) had significantly lower concentrations of MIP-1 $\alpha$ than those observed in control samples (mean $31.20 \mathrm{pg} / \mathrm{ml} ; \mathrm{P}<0.05$ ). Both HIV1-infected and uninfected individuals heterozygous for the $\Delta 32 \mathrm{ccr} 5$ allele had significantly lower concentrations of circulating RANTES (mean 16.07 and $6.11 \mathrm{ng} / \mathrm{ml}$, respectively) than CCR5/CCR5 individuals (mean 28.23 and $16.07 \mathrm{ng} / \mathrm{ml}$, respectively; $\mathrm{P}<0.05$ ). These findings suggest that the CCR5 allele and $B$-chemokine production may affect the immunopathogenesis of HIV-1.
Key words

- HIV-1

- CC chemokine receptor 5

- $\Delta 32$ ccr5 Frequency allele

- Chemokines 
A mutant allele of the $\beta$-chemokine receptor gene CCR5 bearing a 32-bp deletion $(\Delta 32 \mathrm{ccr} 5)$ that prevents cell invasion by the primary transmitting strain of HIV-1 has been recently characterized. The $\Delta 32 \mathrm{ccr} 5$ mutation, which leads to truncation and loss of receptor activity, was remarkable because individuals homozygous for the deleted allele were resistant to HIV-1 infection despite repeated exposure (1-3).

Several reports have suggested an association between exposed uninfected individuals and high levels of endogenous $\mathrm{CC}$ chemokines (macrophage inflammatory protein $1 \alpha$ and $1 \beta$, MIP- $1 \alpha$ and MIP-1 $\beta$ ) and RANTES (regulated-upon-activation, normal $\mathrm{T}$ expressed and secreted), suggesting that a chemokine may contribute to clinical resistance in some cases $(4,5)$. Because the $\beta$ chemokines are major components of the HIV-1 suppressive soluble factor extensively studied nowadays (6-12), the present study was undertaken to determine the relationship between plasma concentrations of MIP$1 \alpha$ and RANTES and viral load in Brazilian HIV-1-infected subjects.

Blood samples were drawn from 26 blood donor volunteers from the Hematology and Hemotherapy Center, Faculty of Pharmaceutical Sciences. One hundred and twentynine samples used for the HIV-1-infected group were remnants of samples sent to the Clinical Immunology Laboratory to be tested for HIV-1 viral load and CD4 T lymphocyte count. HIV-1-infected individuals with opportunistic infection were excluded from data analysis. This study was approved by the Research Ethics Committee of the Faculty of Pharmaceutical Sciences, São Paulo State University. DNA was extracted from leukocytes by the salting-out method (13).

The HIV-1 RNA load was determined from plasma frozen at $-80^{\circ} \mathrm{C}$ using the Nuclisens assay (Organon Teknika, Boxtel, The Netherlands) according to the method indicated by the manufacturer. The dynamic range of the assay is 1.9 to $6.0 \log \mathrm{RNA} / \mathrm{ml}$ of plasma and the sensitivity is $1.9 \mathrm{log} / \mathrm{ml}$. Measurements lower than $1.9 \mathrm{log} / \mathrm{ml}$ were considered to be equal to $1.9 \mathrm{log} / \mathrm{ml}$ for the purpose of statistical analysis. The CD4 and CD8 lymphocytes were quantified by flow cytometry (Becton-Dickinson Immunocytometry Systems, San Jose, CA, USA).

Genotypic analysis of the CCR5 alleles was performed using the oligonucleotide primers reported by Rubbert et al. (14) covering nucleotides 533-553 (5'oligo-TTCATT ACACCTGCAGCTCTC) and 685-712 (3'oligo-CAGAGCCCTGTGCCTCTTCTT CTCATTTCG) of the CCR5 gene in PCR procedures. Using this set of primers, the wild-type CCR5 allele gives rise to a PCR product of $180 \mathrm{bp}$, whereas the deleted allele is $148 \mathrm{bp}$. Genomic DNA (50-100 ng) from each individual was amplified in a total volume of $20 \mu \mathrm{l}$ in a buffer containing $20 \mathrm{mM}$ Tris- $\mathrm{HCl}, \mathrm{pH} 8.4,50 \mathrm{mM} \mathrm{KCl}, 1.5 \mathrm{mM}$ $\mathrm{MgCl}_{2}, 0.2 \mathrm{mM}$ of each primer, $1 \mathrm{U}$ Taq polymerase, $20 \mathrm{mM}\left(\mathrm{NH}_{4}\right)_{2} \mathrm{SO}_{4}$ and $0.1 \%$ Tween 20. Cycling conditions were $94^{\circ} \mathrm{C}$ for $1 \mathrm{~min}, 55^{\circ} \mathrm{C}$ for $2 \mathrm{~min}$ and $72^{\circ} \mathrm{C}$ for $2 \mathrm{~min}$ for 35 cycles. The reaction products were run on $3 \%$ agarose gel and DNA bands were stained with ethidium bromide.

Plasma levels of RANTES and MIP- $1 \alpha$ were determined by enzyme immunoassay (ELISA) according to manufacturer instructions (R \& D Systems, Inc., Minneapolis, MN, USA). Concentrations of chemokines were calculated from a standard log-log transformation curve and by linear regression.

Comparison of the measured variables between the group homozygous for the CCR5 allele and the group heterozygous for the $\Delta 32 \mathrm{ccr} 5$ allele was made by the Student $t$ test. The values are reported as means and $95 \%$ confidence intervals. Relationships between variables were assessed by the Pearson correlation coefficient. $\mathrm{P}$ values of $<0.05$ were considered to be statistically significant.

Genotypic analysis of the CCR5 alleles was performed by PCR and the allele sizes 
were $180 \mathrm{bp}$ for the normal allele and $148 \mathrm{bp}$ for the deletion allele. Among the Brazilian blood donors studied here ( $\mathrm{N}=26), 88.5 \%$ had the CCR5/CCR5 genotype and $11.5 \%$ had the CCR $5 / \Delta 32 \mathrm{ccr} 5$ genotype. The prevalence among HIV-1-infected Brazilian individuals $(\mathrm{N}=129)$ was $94.6 \%$ CCR $5 / \mathrm{CCR} 5$ and $5.4 \% \mathrm{CCR} 5 / \Delta 32 \mathrm{ccr} 5$. The frequency of the $\Delta 32 \mathrm{ccr} 5$ mutant allele in this population was 0.032 and no homozygous $\Delta 32 \mathrm{ccr} 5$ was detected. The ethnic structure of the Brazilian population is heterogeneous. Europeans, Asiatics, Arabians, Africans and native Amerindians contributed to the formation of the present Brazilian population. The 0.032 frequency of the CCR $5 / \Delta 32 \mathrm{ccr} 5$ mutant allele observed in the present study is comparable to the frequencies found by Passos and Picanço (15). The presence of $\Delta 32 \mathrm{ccr} 5$ at its low frequency in the Brazilian population can be explained by Southern and Mediterranean European (Portuguese, Italian and Middle East) gene flow to Brazil since the 16th century (16).

The 122 HIV-positive patients with the CCR5/CCR5 genotype had significantly lower concentrations of MIP- $1 \alpha$ (mean 26.23 $\mathrm{pg} / \mathrm{ml}$ ) compared to 23 control samples with the CCR5/CCR5 genotype (mean 31.20 $\mathrm{pg} / \mathrm{ml} ; \mathrm{P}<0.05)$. However, RANTES concentrations in plasma samples obtained from the HIV-positive patient group were significantly higher (mean $28.23 \mathrm{ng} / \mathrm{ml}$ ) than in control samples (mean $16.07 \mathrm{ng} / \mathrm{ml} ; \mathrm{P}<0.05$ ). The heterozygous HIV-positive patients (CCR5/A32ccr5) had significantly lower concentrations of RANTES (mean $16.07 \mathrm{ng} / \mathrm{ml}$ ) than HIV-1 individuals homozygous for the CCR5 allele (mean $28.23 \mathrm{ng} / \mathrm{ml}$ ). The uninfected heterozygous individuals had significantly lower concentrations of RANTES (mean $6.11 \mathrm{ng} / \mathrm{ml}$ ) than HIV-1-infected individuals heterozygous for the CCR5 allele (mean $16.07 \mathrm{ng} / \mathrm{ml} ; \mathrm{P}<0.05$ ) (Table 1). Studies have demonstrated that the $\beta$-chemokines RANTES, MIP- $1 \alpha$ and MIP- $1 \beta$ are able to inhibit the replication of HIV-1 $(4,6)$. The mechanism of this inhibition is not yet known but most probably involves steric blockade of the co-receptor by the ligand. Alternatively, chemokine-mediated inhibition of HIV entry may be due to downregulation of the receptor on the surface of permissive cells (17).

There was no significant correlation between the concentrations of $\beta$-chemokine and viral load $(r=0.14$ for MIP- $1 \alpha$ and $r=$ 0.10 for RANTES); however, a significant inverse correlation was evident between CD4+ T cell count and plasma concentrations of RANTES $(\mathrm{r}=-0.21, \mathrm{P}=0.022)$. Notably, a correlation was found between MIP- $1 \alpha$ and RANTES $(r=0.22, \mathrm{P}=0.017$ ) (Table 2). The present study explored the possible relationship between the concentrations of $\beta$-chemokines and HIV-1 viral load

\begin{tabular}{|c|c|c|c|c|}
\hline \multirow[t]{2}{*}{ Parameters } & \multicolumn{2}{|c|}{ CCR5/CCR5 } & \multicolumn{2}{|c|}{ CCR5/ $332 \operatorname{ccr} 5$} \\
\hline & Control & HIV-1-infected & Control & HIV-1-infected \\
\hline RANTES (ng/ml) & $16.07^{a}(10.38-21.75)$ & $28.23^{b}(27.04-32.38)$ & $6.11^{\mathrm{a}}(-0.70-12.93)$ & $16.07^{b}(7.36-24.79)$ \\
\hline MIP-1 $\alpha(\mathrm{pg} / \mathrm{ml})$ & $31.20^{\mathrm{a}}(29.24-33.16)$ & $26.23^{b}(25.18-27.29)$ & $34.36(18.32-50.40)$ & $26.97(22.34-31.60)$ \\
\hline Viral load (log RNA/ml) & & $3.62(3.40-3.84)$ & & $4.43(3.46-5.40)$ \\
\hline CD3/CD4 (cells/mm³) & & 356 (313-398) & & $346(105-586)$ \\
\hline CD3/CD8 (cells/mm³) & & 866 (796-935) & & $1004(715-1294)$ \\
\hline
\end{tabular}

Data are reported as means and 95\% confidence interval.

$\mathrm{P}<0.05$ : a vs $\mathrm{a}$, a vs $\mathrm{b}, \mathrm{b}$ vs $\mathrm{b}$ for RANTES and MIP-1 $\alpha$ (Student $t$-test). 
in plasma. The absence of a correlation between ß-chemokine concentration and HIV viral load could be due to a balance between the viral suppressive effects of endogenous $ß$-chemokine and the viral inductive effects of the other cytokines.

Our data demonstrated that HIV-1infected patients with the normal allele (CCR5/CCR5) had significantly reduced plasma concentrations of MIP- $1 \alpha$ compared to uninfected individuals with the normal allele. However, these HIV-1-infected individuals showed significantly higher concentrations of RANTES than controls. These findings are in agreement with Krowka et al. (8). However, Kakkanaiah et al. (9) found lower RANTES concentrations in HIV-positive patients compared to healthy controls. RANTES concentrations in their healthy control group were significantly higher than in our control samples. The reason for this difference is not known, although it may be due to variations among the individuals studied. One possible explanation for the lower MIP-1 $\alpha$ plasma concentrations could be that

\begin{tabular}{|c|c|c|c|c|}
\hline & $\mathrm{CD} 8$ & Viral load & RANTES & MIP-1 $\alpha$ \\
\hline CD4 & $\begin{aligned} r & =0.25 \\
P & =0.006\end{aligned}$ & $\begin{array}{l}r=-0.38 \\
P<0.001\end{array}$ & $\begin{aligned} r & =-0.21 \\
P & =0.022\end{aligned}$ & $\begin{array}{c}r=0.01 \\
P=0.874\end{array}$ \\
\hline $\mathrm{CD} 8$ & & $\begin{array}{l}r=-0.11 \\
P=0.223\end{array}$ & $\begin{aligned} r & =0.13 \\
P & =0.155\end{aligned}$ & $\begin{array}{c}r=0.02 \\
P=0.803\end{array}$ \\
\hline Viral load & & & $\begin{aligned} r & =0.10 \\
P & =0.296\end{aligned}$ & $\begin{array}{c}r=0.14 \\
P=0.128\end{array}$ \\
\hline RANTES & & & & $\begin{array}{c}r=0.22 \\
P=0.017\end{array}$ \\
\hline
\end{tabular}

the HIV-1 Tat protein may cause downregulation of mRNA and suppress the secretion of MIP- $1 \alpha$ and MIP-1ß $(5,18)$. In a recent study, MIP-1 $\alpha$ was shown to have a 10-fold higher affinity than RANTES for CCR5 (19). Thus, variations in ligand affinities for CCR5 could be relevant. Both HIV1-infected and uninfected individuals heterozygous for $\Delta 32 \mathrm{ccr} 5$ had significantly lower concentrations of circulating RANTES than individuals homozygous for the CCR5 allele (CCR5/CCR5). Although our sample size was limited, heterozygous individuals seemed to show differences in RANTES concentrations. In contrast, Yang et al. (10) demonstrated that $\beta$-chemokine values did not differ significantly between individuals homozygous for the normal CCR5 allele and heterozygous individuals.

The natural history of HIV-1 infection varies among individuals and is the result of the complex interaction between the virus and the host immune response. The disregulations in $\beta$-chemokine pathways may affect the immunopathogenesis of HIV-1 depending on the level of immunodeficiency, although via an unknown mechanism in vivo.

\section{Acknowledgments}

We would like to thank Ana Paula Munhoz and Milton Aurélio Marques da Silva, Núcleo de Atendimento à Comunidade, Pharmaceutical Sciences Faculty, UNESP, Araraquara, SP, Brazil, for technical assistance wih the CD4/CD8 count and viral load methods. We are grateful to Dr. Romeu Magnani (Chemistry Institute, São Paulo State University, Araraquara, SP, Brazil) for statistical analysis. 


\section{References}

1. Dean $M$, Carrington $M$, Winkler $C$, Huttley GA, Smith MW, Allilmets R, Goedert JJ, Buchbinder SP, Vittinghoff E, Gomperts E, Donfield S, Vlahov D, Kaslow R, Saah A, Rinaldo C, Detels R \& O'Brien SJ (1996). Genetic restriction of HIV-1 infection and progression to AIDS by a deletion allele of the CKR5 structural gene. Science, 273: 1856-1862.

2. Liu R, Paxton WA, Choe S, Ceradini D, Martin SR, Horuk R, MacDonald ME, Stuhlmann H, Koup RA \& Landau NR (1996). Homozygous defect in HIV-1 coreceptor accounts for resistance of some multiply-exposed individuals to HIV1 infection. Cell, 86: 367-377.

3. Samson M, Libert F, Doranz B, Rucker J, Liesnard C, Farber CM, Saragosti S, Lapoumeroulie Cognaux J, Forceille C, Muyldermans G, Verhofstede C, Burtonboy G, Georges M, Imai T, Rana S, Yi Y, Smith R, Collman R, Doms R, Vassart G \& Parmentier M (1996). Resistance to HIV-1 infection in Caucasian individuals bearing mutant alleles of the CCR- 5 chemokine receptor gene. Nature, 382: 722-725.

4. Paxton WA, Martin SR, Tse D, O'Brien TR, Skurnick J, VanDevanter NL, Padian N, Braun JF, Kotler DP, Wolinsky SM \& Koup RA (1996). Relative resistance to HIV-1 infection of CD4 lymphocytes from persons who remain uninfected despite multiple high-risk sexual exposure. Nature Medicine, 2: 412-417.

5. Zagury D, Lachgar A, Chams V, Fall LS, Bernard J, Zagury JF, Bizzini B, Gringeri A, Santagostino E, Rappaport J, Feldman M, O'Brien SJ, Burny A \& Gallo RC (1998). $\mathrm{C}-\mathrm{C}$ chemokines, pivotal in protection against HIV type 1 infection. Proceedings of the National Academy of Sciences,
USA, 95: 3857-3861.

6. Cocchi F, DeVico AL, Garzino-Demo A, Arya SK, Gallo RC \& Lusso P (1995). Identification of RANTES, MIP-1alpha, and MIP-1beta as the major HIV-suppressive factors produced by CD8+ T cells. Science, 270: 1811-1815.

7. Mackenzie SW, Dallalio G, North M, Frame P \& Means RT (1996). Serum chemokine levels in patients with nonprogressing HIV infection. AIDS, 10: F29F33.

8. Krowka JF, Gesner ML, Ascher MS \& Sheppard HW (1997). Lack of associations of chemotatic cytokines with viral burden, disease progression, or lymphocyte subsets in HIV-infected individuals. Clinical Immunology and Immunopathology, 85: 21-27.

9. Kakkanaiah VN, Ojo-Amaize EA \& Peter JB (1998). Concentrations of circulating ß-chemokines do not correlate with viral load in human immunodeficiency virusinfected individuals. Clinical and Diagnostic Laboratory Immunology, 5: 499-502.

10. Yang JY, Togni M \& Widmer U (1999). Heterozygous defect in HIV-1 coreceptor CCR5 and chemokine production. Cytokine, 11: 1-7.

11. Cocchi F, DeVico AL, Yarchoan R, Redfield R, Cleghorn F, Blattner WA, GarzinoDemo A, Colombini-Hatch S, Margolis D \& Gallo RC (2000). Higher macrophage inflammatory protein (MIP)- $1 \alpha$ and MIP$1 ß$ levels from CD8+ $T$ cells are associated with asymptomatic HIV-1 infection. Proceedings of the National Academy of Sciences, USA, 97: 13812-13817.

12. Paxton WA, Neumann AU, Kang $S$, Deutch L, Brown RC, Koup RA \& Wolinsky SM (2001). RANTES production form
CD4+ lymphocytes correlates with host genotype and rates of human immunodeficiency virus type 1 progression. Journal of Infectious Diseases, 183: 1678-1681.

13. Miller SA, Dykes DD \& Polesky HF (1998). A simple salting out procedure for extracting DNA from human nucleated cells. Nucleic Acids Research, 16: 1215.

14. Rubbert A, Combadiere C, Ostrowski M, Arthos J, Dybul M, Machado E, Cohn MA, Hoxie JÁ, Murphy PM, Fauci AS \& Weissman D (1998). Dendritic cells express multiple chemokine receptors used as coreceptors for HIV entry. Journal of Immunology, 160: 3033-3041.

15. Passos GAS \& Picanço VP (1998). Frequency of the $\Delta$ ccr5 deletion in the urban Brazilian population. Immunology Letters, 61: 205-207.

16. Martinson JJ, Chapman NH, Rees DC, Liu YT \& Clegg JB (1997). Global distribution of the CCR5 gene 32-basepair deletion. Nature Genetics, 16: 100-103.

17. Picard L, Simmons G, Power CA, Meyer A, Weiss RA \& Clapham PR (1997). Multiple extracellular domains of CCR- 5 contribute to human immunodeficiency virus type 1 entry and fusion. Journal of Virology, 71: 5003-5011.

18. Sharma $V, X u M$, Ritter LM \& Wilkie NM (1996). HIV-1 tat induces the expression of a new hematopoietic cell-specific transcription factor and downregulates MIP-1 alpha gene expression in activated T-cells. Biochemical and Biophysical Research Communications, 223: 526-533.

19. Aramori I, Ferguson SSG, Bieniasz PD, Cullen BR \& Caron MG (1997). Molecular mechanism of desensitization of the chemokine receptor as an HIV-1 co-receptor. EMBO Journal, 16: 4606-4616. 